\title{
JACOB BURCKHARDT AND HIS ATHENS OR HOW TO SHAPE AN AUTHORITARIAN DEMOCRATIC STATE ${ }^{1}$
}

\author{
Guilherme Moerbeck* \\ Recebido em: 11/08/2018 \\ Aprovado em: 18/11/2018
}

\begin{abstract}
This article was organized in three parts. In the first one, a concise introduction to the History of Greek Culture and its historical environment is presented. The focus of the second part lies on Burckhardt's ideas on the emergence of the polis in Ancient Greece, and how the main thoughts of the Swiss historian tend to materialize in the Ancient past some theoretical conceptions of the nineteenth century. The Athens of Burckhardt is analyzed in the final part of this paper; the core of the author's approach, and the way he built the idea of the "state as evil" to the democratic Athens of the fifth and the sixth centuries BC are explained. At last, the very meaning of Burckhardt's Athens - a city-state degenerated by the government of its demoralized mob rule -, is discussed.
\end{abstract}

KEYWORDS: Jacob Burckhardt; polis; historiography; History of Greek Culture; ancient democracy.

\section{JACOB BURCKHARDT E SUA ATENAS OU COMO FORJAR UM ESTADO DEMOCRÁTICO AUTORITÁRIO}

RESUMO: Este artigo foi organizado em três partes. Na primeira, é desenvolvida uma síntese da obra $A$ História da Cultura Grega e do seu contexto histórico de produção. $\mathrm{O}$ foco da segunda parte está relacionado às ideias de Burckhardt que concernem à emergência da pólis na Grécia antiga, bem como às principais concepções do historiador suíço que tendem a transpor para a Antiguidade algumas reflexões teóricas inerentes ao decurso do século XIX. A Atenas de Burckhardt é caracterizada na parte final deste artigo, que pretende explicar como ele construiu e sobrepôs a ideia do "estado como mau" para a Atenas democrática dos séculos

\footnotetext{
${ }^{1}$ Pesquisa financiada pelo Conselho Nacional de Desenvolvimento Científico e Tecnológico (CNPq).
}

* Professor Adjunto, Departamento de Arquitetura e Urbanismo, ESDI/ UERJ; professor colaborador no PROF HISTÓRIA/UERJ, e PPGH/UERJ. Pós-Doutorando junto ao LABECA

- Laboratório de Estudos Sobre a Cidade Antiga, MAEUSP. gmoerbeck@yahoo. com.br 
V e IV a.C. Dessa forma, intenta-se pôr em debate a Atenas de Burckhardt, uma cidade-estado degenerada por um governo popular corrompido.

PALAVRAS-CHAVE: Jacob Burckhardt; Pólis; Historiografia; História da Cultura Grega; democracia antiga.

\section{INTRODUCTION: THE LANDMARKS OF THE GRIECHISCHE KULTURGESCHICHTE}

$\mathrm{t}$ the beginning of the study of the History of Greek Culture, we must be aware of
some characteristics of this oeuvre. Firstly, we should be alert that it was hardly
ever thought of as a book or as a set of articles to be transformed into a consistent and logical intellectual work. It does not mean that the History of Greek Culture is a nonsense piece of an erudite German mind of the nineteenth century. The very birth of this book was in the years around 1864, when Burckhardt began to compose some lectures, not directed towards classicists only, but opened to a broader public (Burckhardt, 1999, p. 6-7). However, the formal decision to prepare the lectures came only between 1869 and 1870, beginning, in fact, in 1872.

At some point, Burckhardt considered publishing the lectures. Indeed, he had made changes in the form and revisions in the parts which were, in the posthumous publication, the first two volumes. The other parts remained just as lecture notes (Murray, 1999, p. XXXIII). In any case, over the years, Burckhardt completely relinquished the idea of publishing his classes on Greek culture. In fact, he was not in the state of mind to raise academic questions with whom, ironically, he called the viri eruditissimi, that is, the members of what roughly can be named the mainstream of the European Academy and, especially, of German language of his time (Murray, 1999, p. XXXIII-IV). Christ reminds us that it was Burckhardt's nephew, Jacob Oeri, who posthumously published his uncle's lectures in the form of a book, separated in four volumes (Christ, 2000, p. 106; Sieber, 1997, p. 93-4; Gilbert, 1986; Rodrigues, 2013). Burckhardt's fears are justified given that the German Historical School's reception of his book was icy and full of voracious criticism. Seemingly, Burckhardt had entirely left aside the academic production and even the relevant discoveries of papyri of the time; whereas, not surprisingly, the book found great success outside the more closed circles of the German academy. He had been accused by several authors, such as U. Wilamowitz and E. Meyer, of failing to critique sources. Arnaldo Momigliano emphasizes that, indeed, Burckhardt did not seem strictly up-to-date on the evolution of classical studies since the time of his youth (Momigliano, 2012, p. 297-8; Moerbeck, 2018).

But what was the very reason for writing those lectures? Escapism of the fast-social transformations, the idealism of the Greek life and culture, fears about contemporary European life, or just an attempt to offer a sort of different and better Greek history course, methodologically speaking, from his times as a student? There was a little bit of each reason in Burckhardt's mind. Note that the volume organizations themselves correspond to Burckhardt's methodology. A clear example of this is that the nine sections which divide the 
first three volumes correspond, respectively, to the discussions surrounding the State, religion, and culture (Murray, 1999, p. XXXV). For our study, the most important pieces are in the first volume, where Burckhardt discusses the nature of the polis and Athenian democracy.

In the introduction of the first volume, Burckhardt mentions August Boeckh's lectures, pointing out that those called "Greek Antiquities" are of great relevance to the full understanding of the Greek way of life, but for his purposes it was necessary that we "select only what most strikingly illustrates the Greek views of life" (Burckhardt, 1999, p. 4). The central aim of the historian was to leave aside the narrative of the events, especially the political ones, as a form of validating the historical speech. Besides, he intended to create a study that was not of a narrative and chronological genre, but rather, an approach to the peculiarities and the ethos of the Greek spirit, so: "It is the history of Greek mind or spirit that must be the aim of the whole study. The details and even what are called events can appear only as supporting testimony to the general, not for their own sake [...]" (Burckhardt, 1999, p. 4).

Momigliano asserts that, according to the Swiss author, the chronological order obscures the essential importance of the individual. Thus, a document, considering Burckhardt's studies, was a way of thinking, far removed from the problems connected with the objective truths that someone could naively try to emerge from the ordering of facts. He considered that it was indeed possible to penetrate the spirit of a people and the structure of their political organization. Although the organization of the lectures corresponds to his methodological approach, it should be stressed that there was a significant part of the second volume that was organized in chronological order. Finally, it might be relevant to say that Burckhardt's intention was a sort of compromise between the two forms of compositions (Momigliano, 2012, p. 296-7).

Burckhardt thought that, by using a methodology and theory to think in another way, the sources would respond in an entirely different fashion from that of the antiquity researchers. The truth of events narrated by sources is a problem that a factual history is concerned with, which would not be the case for the cultural historian. If there were lies in some Greek sources, this was also of interest in Cultural History because it reveals how those people express themselves. The process of research of Cultural History ends up evaluating what is more constant and not the temporary actions. Attitudes and desires communicate more about a society than any other action that someone might have performed. The inner structure of what might be called the "eternal Greek" was what Burckhardt has sought as a form of knowledge. Individuals do not disappear in his writings, but they are an illustration and witness of the things of the spirit.

To sum up, what is recurrent is more relevant than what is unique (Burckhardt, 1999, p. 6-7). Concerning that, we should inquire, how could this "eternal Greek" be understood? One of the Burckhardt's answers guide us to the problem of the relation between the individuals and the State, and it is what will be under discussion from now on. 


\section{THE ANCIENT GREEK POLIS: BETWEEN THE MODERN AND THE ANCIENT WORLDS}

Inspired by Aristotle's Politics, Fabio Augusto Morales once questioned himself about a possible definition of the polis. On the one hand, it is valuable to raise a question about how the Greeks imagined and defined their meaning or their poleis, in an anthropological approach - Mogens Hansen has exhaustively developed this kind of research (Hansen; Nielsen, 2005). On the other, and this is the core of our work, we may raise a question about how historians have imagined and defined the Greek experience of the polis. In that way, Morales asked: what gives unity to Greek history? Thus, he creates a sort of taxonomy to explain the different approaches and understandings of the poleis and the city-states. Such as the religious city, analyzed by authors like Fustel de Coulanges and François de Polignac; the state-consumer city covered by Max Weber and Moses Finley; the modern city encompassed by E. Meyer and M. Rostovtzeff. The city of classes encompassed by S. Utchenko, G. de Ste. Croix and Ellen Meikisins-Wood; the institutional city imagined by G. Glotz and M. Hansen and the philosophical-existential city handled by Jean-Pierre Vernant and C. Meier. ${ }^{2}$

All that effort is meaningful because it creates a grid which summarizes the contribution of almost countless academic works and theses on this matter. However, we should mention that Morales did not include Burckhardt in his account. The fact is, to classify the Swiss historian in just one of those categories would have been a challenge. Every taxonomy simplifies the reality, thus, apparently, it does not comprehend all the possibilities. So, it is better to imagine these ranks as Weberian ideal-types - in that way, we may not necessarily remain tied to a simple definition, but navigate among them (Morales, 2014, p. 47-82).

M.B. Sakellariou once asserted that the polis was understood as the exclusive type of Greek state by Burckhardt. In this author's opinion, the polis differed both from the Phoenician city-states and the modern European city-republics. The critical element in this interpretation is the idea that in the polis there was the predominance of the whole over the individual. Contrastingly, European cities had belonged to already existent states in Europe and had the power of the Catholic Church over them (Sakellariou, 1989). Following the same path, Norberto Guarinello argues that Burckhardt was responding to Herder's 1776 text about the definition of a Greek form of state which corresponded to the unity of its culture. The concept of polis emerges, then, to fulfill this function of uniting Greek culture through an essential structure of all Greek poleis. The polis is both a state and a community. These independent states were the cause which prevented a more significant association - a nation, for instance. It is the polis that shapes the Greek spirit and culture because it forms the character of men in the political contest between equals (Guarinello, 2009, p. 109-19).

Burckhardt's preamble is about the origin of the polis, as he argues, the social foundations of Greek life are family, honor and property rights. He believes that there must

\footnotetext{
${ }^{2}$ A fascinating account about the modern historiographical approaches of the ancient Greek city is into Unthinking the Ancient Greek Polis (Vlassopoulos, 1997, p. 13-45; p. 121-41). Unfortunately for our purpose, there are just a few pages concerning Burckhardt's oeuvre.
} 
have been a kind of "primitive religion" that had performed a central role in the worship of ancestors, the house and its place. From these cults appeared the cohesion of the family and the idea of monogamy. The worship of dwellings and burial sites would have established the right of property. The plots of land contained the graves of the dead, so how could they be alienated without shame? Thus, the cult of the dead was directly linked to the law of succession. It is almost unnecessary to mention that Burckhardt indeed borrowed these ideas from Fustel de Coulanges in his La Cité Antique (Fustel, 2009, p. 69-77).

According to Burckhardt, the genos no longer existed at the time when the earliest forms of the polis appeared. It was therefore known as an ancient tradition, like the custom connecting families to their land. These strong connections remained in the earlier past, and the genoi took on another form in Archaic and Classical periods, with resulting changes to familial relations. What Burckhardt wanted to say is that the ancient traditions, an amalgam of the heroic Greek times expressed in mythology and literature, united communities through land ownership. Local religion and ancestry became progressively weak, as the polis strengthened (Burckhardt, 1999, p. 37-8; p. 42). To Burckhardt, the polis was:

[...] the definitive Greek form of State; it was a small independent state controlling a certain area of land in which scarcely another fortified position and certainly no secondary independent citizenship were tolerated. This state was never thought of as having come into being gradually, but always suddenly, as a result of a momentary and deliberate decision (Burckhardt, 1999, p. 43).

We must underline two facts here. The first is the characteristic Greek form of organizing their koinonia, as stated by Sakellariou and Guarinello above. This state used to have a fortress. Burckhardt is probably also thinking about great walls which usually surrounded the cities. The second fact, and more relevant, is the idea of the polis as a self-governing being. This view is a very well-known and much-debated statement taken from Aristotle's Politics. ${ }^{3}$ However, the core of Burckhardt's argument was born in the idea of intolerance among the poleis. This has begun with the impulse for this materialization, the synoecism - a process in which small communities united around a core/city as a fortress.

\footnotetext{
${ }^{3}$ It is impressive how Aristotle Politics, especially the third book, became the primary source to conceive the ancient Greek polis in the authors of the nineteenth century and into the beginning of the next one. It is not difficult to perceive this feature in Fustel de Coulanges, La Cité Antique, as well as Max Weber's Economy and society, mainly in the part Die nichtlegitime Herrschaft: Typologie der städte, written between 1911-13, published in 1920 in a volume of the Archiv für Sozialpolitik, and finally published into the book organized by his widow, Marianne Weber (Weber, 1974, 1212ff.; Nippel, 1991, p. 19-30). Even in Marx's Grundrisse, into the Formen, we can see the relevance of Aristotle ideas. It is worthy to say that these authors became of the utmost importance to historiography until the last quarter of the twentieth century, when a new approach, less concerned with the polis itself, and more with Mediterranean connections arise.
} 
[...] the chief consideration was to establish a strong political entity and to be prepared to resist neighboring poleis in which the same process was at work. If the aim had been merely trade, material prosperity and so forth, the result would have been just a town or a city, but the polis was more than that (Burckhardt, 1999, p. 44).

To the author there was another raison d'etre, just an economic explanation would not be robust enough to convince him. There was something beyond, something which could better explain this "Hobbesian war of all poleis against all poleis." So, there was an external component in Burckhardt's interpretation of the formation of the poleis. Migrations have caused a set of battles that resulted in several populations seeking different forms of protection. The emergence of the polis marked a new moment in Greek History in which these towns confronted each other for the sake of their existence and political power. Burckhardt considered that both fear and political protection provided by the polis had driven the Greeks towards the purpose of creating poleis but, as we shall see, they do not fully explain Burckhardt's concerns.

We must be aware that, for Burckhardt, the problem of the advent of the poleis was deeply rooted in violence. What Burckhardt began to stitch together is that the development of Greek culture was directly linked to the development of the poleis, so, it ends up being subordinated to the development of politics and a State. A question that we should raise here is: was the formation of the State troublesome in Antiquity, as well as the modern one? There is a strong temptation to easily link this fact with the German unification process, as far as Basel's bumpy ride during the creation of a united Switzerland. However, let us put these conclusions aside for a while, and let Burckhardt's thoughts guide us. The interpretation of the author leads us to believe that the process of synoecism had an enormous human cost which involved struggles and resettlements, which took the Greeks away from the lands they cultivated and from the graves of their dead. The formation of the polis was ultimately, and somehow paradoxically, the way found by the Greeks to fight against the violence created by their form of territorial and institutional organization (Burckhardt, 1999, p. 45-6).

For Lionel Gossman, Burckhardt was aware of the differences of the Swiss of his time and the poleis of Ancient Greece. While the small republics that emerged at the end of the middle ages dealt with the breaking up of something more significant, the poleis are the culmination of a process of absorption and integration, where the resistance of smaller units continued to exist (Gossman, 2003, p. 54). We should remember that for Burckhardt the emergence of the state is violent and has a very high human cost. The rise of the state is always linked to power and domination of the weaker, subservient and conquered. We may understand that the violence spread through the synoecism phenomenon developed a sort of chain reaction in the emergence of the poleis. So, the State became a form of protection against violence, but which internally caused almost unbearable violence, while it destroyed ancient structures of social relations and traditions. A precise comprehension of this process is just possible by debating the relationship between the individual and the community. 
In his analysis, Burckhardt makes a comparison considering the State and the individual between ancient and modern times. In the latter, persons create the State because of their needs. The main one is security, insomuch that they can fully develop all their potential. The offer of individual sacrifices in return for the state is coldly calculated. "The Greek polis, by contrast, starts from the whole, which is conceived as chronologically prior to the part. It is not only the general taking precedence over the particular but also the eternal over the momentary and the transient." (Burckhardt, 1999, p. 55). Thus, the citizen must give himself to the whole not only in the battlefield, sacrificing his life, but also in other spheres to have the security of existence among his peers, which is restricted to their poleis. It means that "even the most meritorious citizen has always owed more to his native city than the city did to him" (Burckhardt, 1999, p. 56).

Even if Burckhardt's conclusion about the tense relations between the individual and State in Ancient Greece differs from the same modern phenomenon, the fact is that the author used the equal measure for both ages. The point is that Burckhardt weighed up modern and ancient men on the same scale, not in his conclusion, but at the begging of his hermeneutic process. In this way, comparing the ancient and the modern citizen around the level of liberty that they supposedly have, presupposes an evaluation that the degree of freedom can be placed on the same spectrum in these different ages. Departing from Burckhardt's assumptions, it will be impossible to see the relation between the individual and the State without incurring in an anachronical and biased assessment, i.e., that the Greeks were devastated by their state. Why, so, endure and not revolt against this overbearing state? Perhaps, the Athens example would figure out this point.

\section{Athens: or How to SHAPE an AUThoritarian Democratic STATE}

Burckhardt, in general, defines the polis as the only way for citizens to accomplish all their virtues. Thus, Greeks could only reach their full spirit through the participation in the State. Besides, the polis was a tremendous educative force. The very point is that the polis could provide to its home fellows a vast range of rituals - especially religious ones -, works of art, public speeches, poetry (including the theatre) and family education could reinforce the cultural values and tie human beings to their homeland, their polis. Despite the idea that the Greek State completely subordinated the individual to the community, it had as well, controversially, a strong tendency to encourage individuality, since "[...] freedom and subordination should have been fused in harmonious unity." (Burckhardt, 1999, p. 556; p. 60). Therefore, these individual forces should at least be involved in the community interest. In this way:

Internally, the polis was implacable towards any individual who ceased to be totally absorbed in it. [...] The polis was completely inescapable, for any desire to escape entailed a loss of all personal security. The absence of individual freedom went hand in hand with the omnipotence of the State in every context. Religion, the sacral 
calendar, the myths - all these were nationalized, so that the State was at the same time a church, empowered to try charges of impiety, and against this dual power the individual was totally helpless. [...] In short, there could be no guarantees of life or property which could run counter to the polis and its interests. [...] Thus, the polis got the maximum price for the small amount of security it afforded (Burckhardt, 1999, p. 57-8).

Even if everybody was not centered on individual life, but in how men performed through and for the polis, considering the polis as a church, a very pure form of faith, a religion itself, could we even name it as a totalitarian state? According to Christoph Marx:

Burckhardt's characteristics of the polis were once compared by Benedetto Croce to a breeding house, and indeed the polis in Burckhardt appears as a totalitarian State which leaves no individual freedom to the individual - or to use a modern formulation - in which all private is public. It is incalculable that Burckhardt's ontological interpretation of the polis was strongly inspired by the ideal image of the polis, which Aristotle drew in his politics. After that, the polis first appoints man as a free man in the true sense of the word, according to the multidiscipline Aristotelian dictum, that man is a natural political animal (zoon politikon). To this Greek idea that 'freedom and subordination harmoniously merge into one', will be entered in the next section. [...] For Burckhardt, the Greek polis represents the basic type of each State. For Burckhardt, it is always compulsive and violent towards the individual. In view of his above-mentioned maxim that every power in itself is evil, then the basic polis is only the most extreme expression of the principle of potential violence of any State (Marx, 1998, p. 19-20).

Answering the question above, we might not take on this risk. Even if there are some cases of historians assuming a totalitarian dictatorship in Antiquity, like Franz Neumann (1957), the very fact is that the totalitarian state is a contemporary phenomenon and political concept which we could hardly use to make an insightful reading of ancient societies. It means that, as Hannah Arendt (1951) points out, totalitarian states could destroy the web of private relations of humans, depriving them of their selves. Besides, in order to imagine a totalitarian regime, Athens would have needed terror, fostered by the State, and both the practice and the idea of the existence of a unique party and a chief in command of the government. In short, one sine qua non condition of a totalitarian regime is powerful and all-encompassing ideological propaganda. Though we might, at the furthest limits, compare the Athenian State with a totalitarian regime, we could have serious difficulties proving that. ${ }^{4}$ For example: could

\footnotetext{
${ }^{4}$ This does not mean that we do not have to take seriously into account the pressures of the Athenian State over the individuals, mainly after the oligarchic government at the end of the fifth century BC (Shear, 2011, p. 135-65).
} 
we seriously think of Euripides as a sort of propagandist of a democratic state, or even more abstractly, that the government of the masses was an embodiment of an autocratic leader? If it is not the case, then how can we understand the Athens of Burckhardt?

Considering Plutarch in his account Burckhardt mentions that:

At the borders of two epochs was the Athens of Solon, who was able to assure all the people (from $594 \mathrm{BC}$ on) the right to elect his Council..$^{5}$ To those who owned land, usually, the aristocracy was reserved the exclusivity in being elected; [...] in it (Athens), in the ecclesia, where most important resolutions for the city were decided (Burckhardt, 1964, p. 278).

Burckhardt was not sure if Clisthenes and his followers were active creators of democracy or mere artificers of the Athenian spirit of that time. This doubt is probably related to the author's willingness to mitigate the effects of individual policy actions. Burckhardt emphasizes that the ambitious and unscrupulous men who exploited the State were one of the most perverse elements that distinguished ancient democracy, such as Themistocles, surprisingly rich in the days when he was in power (Burckhardt, 1964, p. 280-1). Thus, dialoguing with Fustel de Coulanges, the Swiss historian states that the crucial problem was that:

The poor man, to guard against wicked decisions, had to be able to be judge and magistrate. And considering the enormous power of the polis over existence, the most insignificant had to claim their participation in it. Thus, all the power that was formerly owned by kings, aristocrats, tyrants, now passes into the hands of the people [and the people] are the most suspiciously anxious to react and command, and it is important to point out, at that moment, that those measures were used to defend [the poor] from the influx of individuals of indicated intelligence, the procedure of election of a military leader or ostracism. (Burckhardt 1964, p. 282-3)

For Burckhardt, the ostracism is a clear mob demonstration of a mechanism to exclude those who seem dangerous to democracy. However, rather than operating on fear, it was based more on envy. Ostracism was an institution created from the mistrust of people (Burckhardt, 1964, p. 286). One should be aware that ostracism, a mechanism which ousts a supposed menace to democracy for ten years, was used for "cutting off the heads"

\footnotetext{
${ }^{5}$ Burckhardt does not detail which Council he means - Boule or the Areopagus. At any rate, he is probably speaking of the Boule, because the context of this part of the chapter is discussing the way to Cleisthenes's democratic reforms. The Solonian timocratical reforms divided the citizens into different classes according to how many medimnos (measures) of wheat or their equivalents they achieved per year. The higher class, the pentacosiomedmini, was able to reach the highest offices. For a didactical approach of the Solon reforms, cf. (Bradley, 1991, p. 84-91).
} 
of some of the mainstream actors of the Athenian political arena. However, one ought to distrust the way in which Burckhardt understands ostracism, i.e., as a mechanism shot against the traditional elite of Athens. Ostracism was so feared that soon after the start of its operation, it was considered a hazardous mechanism. The power of ostracism helps us to explain why it was necessary to have a great quorum to put it to a vote (Moerbeck, 2017; Dabdab-Trabulsi, 2004).

The critique of Athenian democratic institutions is only the beginning. Burckhardt sees theorikon, i.e., "payment of theater tickets," banquets and public sacrifices as one of the most harmful notions of democracy. According to the author's reading, even wars were lost because of this thriftless expense. The overlapping of functions in the case of the Athenian state is, in Burckhardt's arguments, a real problem, possibly causing a significant disorder. He also states that the citizen's employees were seasonal (due to elections and ballots); therefore, there were no possible gains in strength and organization from permanence in charge. For example, the grammateus, a secretary, usually a slave, was effectively accountable for administration. Finally, Burckhardt shows himself uneasy with a relevant position of a slave in the administrative affairs of the Athenian democratic system (Burckhardt, 1964, p. 252; p. 291-6).

Quoting several authors, such as Andocides, Demosthenes, and Aristophanes, he attempts to show that the populace had very little respect for Athenian laws. Besides, Burckhardt mentioned the case of a certain Nicomachus, who was responsible for the republication of Athenian laws and created a vast scam, 'having forgotten true laws' in favor of self-created ones. According to Burckhardt, the demos, until the end of the Peloponnesian War, was ambitious and disinterested towards the state. Although there were men like Cimon and Cleinias (father of Alcibiades) who were very generous towards their city, in times of crisis the exploitation of the owners increased sharply, and this was only possible because they could not leave the polis since they could suffer more perils abroad. He further points out that: "It was not advisable to try to avoid the obligation, and during the Peloponnesian War the rich trembled with fear, thinking of the hatred which would arise against them if there were resistance to exploitation" (Burckhardt, 1964, p. 296-9).

Burckhardt is undoubtedly right about the fact that during and in the aftermath of the Peloponnesian War there was an increase in pressure on the wealthier, and that the liturgies became harsher for citizens. However, as Wilson (2000), Moerbeck (2017) and Shear (2011) show us in different oeuvres and spectrums, this process was linked to coup d'états attempts, organized by oligarchs, and connected with a long process of philotimia (search for power) by the elite, which is discussed in the tragic genre, especially in Euripides' works. The truth is that the reading of Burckhardt seems to be a sort of 'witch hunt' against democracy, and we should mention that the Swiss author seemingly even tries to justify the actions of the thirty tyrants at the very end of the war.

That way, Burckhardt began to create an understanding about the problematic and tense relations between the people and the elite, namely: how the richer and most intelligent Athenians suffered more and more with the greed and envy of the people. Citing Plutarch's Life of Nicias, he also mentions that Nicias did not obtain support against the expedition 
to Sicily because the wealthy owners decided to remain silent - probably terrified by the consequences, even they knew that the financial burden would fall on them. Again, based on the Old Oligarch, he states: "But in all ages and all peoples, there is much bitterness in having to make sacrifices for others to have fun" (Burckhardt, 1964, p. 300).

A central proposition in Burckhardt's discourse was that the strength of the polis relied upon their disdain for work, especially that of the banausos - artisan workers. The problem appears when this behavior, in the aristocratic mind suitable just to the aristocrats, was also incorporated by the demos, being, therefore, corrupted. In this undesirable mix, in Burckhardt's view, anyone could feel tremendously powerful in an assembly or court. After all, if during the Aristocratic government misery could even exist, the difference between conditions was most deeply felt when the equality of rights was established. From then on, the poor man had discovered that the vote could override the right of property.

Furthermore, to Burckhardt, the poor used to sell their votes, even more, when acting as judges, although there was a payment to the meetings of the assembly and courts (misthos). There were all kinds of "confiscation" (liturgies) and even exiles overbearing the richer. The desires of the poor overcame "property and [...] its holiness" (Sigurdson, 2004, p. 183; 1990).

Ellen Meikisins-Wood stresses that it was Burckhardt who first developed such an association more elaborately, from an anti-labor stance mixed with the equal rights that would have created the idle mob that threatened property rights. In Burckhardt's opinion, one of the factors for the decline of the polis was the lack of discipline for daily work - the courts became an instrument of exploitation of the wealthier classes. The courts were a kind of opium that sharpened the imagination of the people about the real wealth of the Athenian elite. Thus, in the Swiss historian opinion, it was a mixture of greed and idleness of the masses that functioned as the engine of a democratic system. In fact, for our author, the anti-banausic posture was not a consequence of slavery but an inheritance, a cultural legacy of aristocratic times, in which this was part of an ethos of the nobles. As we have mentioned above, the crucial problem arises when the poor incorporate this aristocratic ethos, this stance of contempt for manual labor.

The last instance that corrupted the city of Athens was not the anti-banausic stance, but, in contrast, Burckhardt states that it was the triumph of labor, banausic, because they became mighty in the restoration of postwar democracy. The demagogues, who "did not even have a liberal education in music and gymnastics" (Burckhardt apud: Meikisins-Wood, 1988, p. 27), would have handled the people better than the aristocracy could. Quite reasonably, Meikisins-Wood states that the anti-banausic stance is an aristocratic posture only, expressed in Xenophon, Plato, Aristotle, and Aristophanes. Could the anti-banausic ideas be treated as universally accepted values, as a cultural norm in Athenian society? Otherwise, are they a myth that Burckhardt came to take as a heuristic element? (Meikisins-Wood, 1988, p. 22-8).

Burckhardt asserts that a legal order could not exist against individual desires. In his opinion, the ideological synthesis of democracy was a strongly anti-baunasic ethos with the combination of equal rights and low work-related esteem. Thus, in some way, the idlers exploited the legal system to threaten the proprietary classes. The institutional political field 
had been torn apart by the battles between the rich and the poor (Moerbeck, 2014; Bourdieu, 2009). Thus, material interests "were a concept that had gained relevance in contemporary discussions about the stability of political and social orders in general" (Flaig, 2003, p. 25). The decline of the ancient Greek polis was analyzed as a possible lesson to the present days. In any case, Flaig emphasizes that, in he History of Greek. Culture, Burckhardt insists that despite class struggles, artistic creativity in the Greek world has become almost unchanged in the face of social and political changes (Flaig, 2003, p. 21-2; 2013).

It seems that Burckhardt feels a kind of solidarity with the intellectuals of Athenian society who suffered from the exploitation from the demos, as well as showing himself sorrowful about the various cases of trials for crimes of impiety. This argument is based on the discourse of the same Athenian intellectuals-philosophers, such as the Socrates of Xenophon, Oeconomicus, 2, or in the Symposium of the corresponding author. Burckhardt insists that the torment of good citizens was the imminent risk of being denounced and prosecuted in the Heliaia, this was so strong that he compared it to the psychological suffering received by the slaves (Burckhardt, 1964, p. 303; 320-1).

Inspired by Fustel de Coulanges, Burckhardt agrees that:

It is not difficult to find the reason that explains this inclination of the demos. The people, diverted from honorable labor and sunk into continual assemblies and tribunals, resembled a rascal, who always thinks of his plate, being dominated by greedy fantasy (Burckhardt, 1964, p. 303).

It is as if the mob, represented by each one of their members, became the tormentors of the rich and their families, while the courts became despicable spectacles. Taking Lysias, XIX: 4-6, and Xenophon, Memorabilia IV, 8.5, Burckhardt tries to show that there was a serious problem of unfounded accusations. After the restoration of democracy, he emphasizes that what prevailed in the popular assembly were rhetorical politicians and demagogues, sycophants, flattery, false testimony, and slander. The Athenians were fickle about their political opinion. There is, in Burckhardt's view, from the end of the Peloponnesian War on, a belief that the Athenians (the demos) used public offices as a platform for personal enrichment. "The public gallery was a harvest of gold" (Cf. Aristophanes, Pluto, v. 377ff).

Indeed, the Athenian state could not live without similar auxiliaries [sycophants]; the Polis, as the absolute royalty, was deified; it had become a religion, it called for the most extreme measures against any kind of deviation [...] But if anything can show us that in Athens the idea of State had exceeded the bearable limits of normal human nature, it is the public recognition of such a social plague, this legal terrorism which remained the same for four hundred years: from the Peloponnesian War, with the same force as before it and persists in the time of the diadochi until the Romans ... only Greek democracy, in its most perfect form, the Athenian, [...] submitted a similar oversight to all citizens of some importance. The mob had no disgust at things that were so nice and natural to them (Burckhardt, 1964, p. 313-4).

This negative view of the sycophants is in several of Demosthenes' speeches. The function of the sycophant is to investigate whether citizens perform their public duties 
properly. Burckhardt makes a comparison of the sycophants with the Spanish Inquisition. In this case, the inquisitors reached the proposed end, since they embodied the sense of the institution, namely: The Catholic Church that persecuted infidels. The sycophant's strategy was merely blackmail and prosecution. Many times, even if there was a fee for leaving the process, the sycophant could get even more by blackmailing the victim, since there wasn't a sincere conviction in the cases. In short, for Burckhardt, the Athenian legal system became the opposite of the almost unchanging disposition of the nomoi, whereas the democratic ethos had an overwhelming tendency to change caused by the "endless promotions of popular decrees (psephismata)." This very period was what Aristotle called the rule of the masses, not the laws (Burckhardt, 1964, p. 59-60).

To Flaig, there is a sort of paradox in Burckhardt thought, namely: the fragility of the State, which could be modified at any moment by the popular will, by the ecclesia, versus its totalitarian aspect, the power to always interfere and control (Flaig, 2003, p. 17). The real purpose of the meetings of the masses was not to attend to the highest principles of the State, but to answer the ambitions of the people, and this was done in a mixture of passion and whims, thus resulting in destructive actions (Sigurdson, 2004, p. 183). Insofar as traditions weakened, the public interest has become an illusion, and the public sphere became a space open for the pursuit of personal interests (Flaig, 2003, p. 114).

Burckhardt's Athens is a sort of derivation of Aristotle's Politics, what could be called radical democracy, the most vicious type of such regime. In that democracy, all decisions were made by all citizens, leaving nothing to the "true laws." One cannot call politeia a government in which the laws can be modified at any moment by the citizens. Democracy has become a corrupt form of government because it was supposedly governed only by one party, acting selfishly, concerning the interests of other parties. Another problem is that it works as a collective and not as citizens who make their decisions individually, that way, the people become a metaphoric monarch governing as a collective tyrant. To their reading, this is not politics, but just despotism (Ober, 1998, p. 333-4).

\section{Conclusion}

It is very tempting to label Burckhardt as one of the historians who modernized Ancient History (Morley, 2000). Indeed, as we have been seeing, Burckhardt had an approach which imposes alien concepts to the examination of ancient culture. Nevertheless, almost every historian is always working with some degree of anachronism (Loraux, 1992, p. 5770). Moreover, one should neither deny the real methodological improvements applied by Burckhardt in his making of History, nor forget the massive scale of written sources that were used by the author in his lectures on Ancient Greek History.

The eulogies and critiques of Burckhardt's work gained the same weight in historiography. On the one hand, Murray said that he abandoned an apologetic and laudatory vision of the Greeks to try to do a new reading, deeply based on period sources and with influences of the philosophical and political thought of his own time. It has generated some of the most critical readings that influenced modern historiography, such as the idea 
of the primacy of the political power in Greek life, which eventually imposed a form of rationality on Greek society. Burckhardt was able to visualize the fundamental importance of the agonal/competitive aspect in Greek life, as well as to make an essential connection between Greek pessimism and its relation to the intensity of the Greek experience of life (Murray, 1999, p. XXXII-XLI).

On the other hand, Momigliano argues that anyone who intends to develop Burckhardt's ideas should be aware of the two periods in which the History of Greek Culture is rooted. Burckhardt is dialoguing with German romanticism and has a sort of a "laziness with regard to chronology." But, at the same time, he has made " $[\ldots]$ an examination of the complex and contradictory roots of Greek culture [which] is an anti-romantic and revolutionary book, comparable with Nietzsche's Die Geburt der Tragödie, but, although sharing many of its prejudices, far more realistic and sincerely humane" (Momigliano, 2012, p. 303). The point that is stressed here is, to what extent should we seriously consider the account of the History of Greek Culture today, insofar as it appears to us as a strongly biased speech?

The arguments of Burckhardt about the Greek polis are paradoxical. The individual is the author's unit of analysis. Nevertheless, the polis, the very communities of the Greeks, were inescapable, omnipotent. So, how could he save himself from the philosophical cul$d e-s a c$ ? For Burckhardt, it was not necessary, because he decided to work with a blind alley. The citizens accomplished their virtues in the polis, the very place where the individual lost his freedom but, at the same time, did unique things. Selectively, in the following decades, these unique things will be politically used to form the base, or the glorious past, of the so-called European Culture.

However, these accomplishments were not equal for all its citizens. The fact is that the polis came to entropy. Even though Burckhardt has not used the word entropy, the process is explained by the decay of the aristocratic values during the Archaic and especially the Classical Period. The wealthier, progressively exploited by the demos, saw their life values taken by an idle and aggressive mob. The mob was incorporating itself into the core of the Athenian democratic institutions while the state became progressively tyrannical towards dissonant voices. From modern Prussia to ancient Athens, the State was evil. It was wicked with the interests of the traditional and educated elite, with the fastening of social change, and with the conservative mind. Athens was an example to illustrate and to be avoided. Despite all the sheen of the Greek spirit, Athens became, paradoxically, an authoritarian democratic State.

\section{REFERENCES}

ARENDT, Hannah. As origens do totalitarismo. São Paulo: Companhia das Letras, 2013.

BOURDIEU, Pierre. O senso prático. Petrópolis: Vozes, 2009.

BRADLEY, Pamela. Ancient Greece: Using evidence. Melbourne-London: Edward Arnold, 1991. 
BURCKHARDT, Jacob. The Greeks and Greek civilization. Oswyn Murray Editor, translated by Sheila Stern. New York: St. Martin's Griffin, 1999.

BURCKHARDT, Jacob. Historia de la Cultura Griega. Trad. Eugenio Imaz. Barcelona: Obras Maestras, 1964. v. I.

CHRIST, Karl. Weg sur “Griechischen Kulturgeschichte”. Historia: Zeitschrift für Alte Geschichte, Bd. 49, H.1, p. 101-25, $1^{\text {st }}$ Qtr., 2000.

DABDAB-TRABULSI, José Antônio. Ensaio sobre a mobilização política na Grécia Antiga. Belo Horizonte: UFMG, 2001.

FLAIG, Egon. Jacob Burckhardt, Greek culture and modernity. In: Bulletin of the Institute of Classical Studies. Supplement, n. 79. Out of Arcadia: Classics and politics in Germany in the age of Burckhardt, Nietzsche and Wilamowitz, 2003, p. 7-39.

FLAIG, Egon. To act with good advice: Greek Tragedy and the democratic political sphere. In: ARNASON, Johann P.; RAAFLAUB, Kurt A.; WAGNER, Peter. (Org.). The Greek Polis and the invention of democracy: A political-cultural transformation and its interpretations. Malden: Wiley-Blackwell, 2013, p. 71-98.

FONTANA, Josep. História: Análise do passado e projeto social. Bauru: Edusc, 1998.

FUSTEL DE COULANGES, N. D. La Cité Antique: étude sur le culte, le droit, les institutions de la Grèce et Rome. Cambridge: Cambridge University Press, 2009[1864], facsimile.

GILBERT, Felix. Jabob Burckhardt's student years: The road to Cultural History. In: Journal of History of Ideas, v. 47, n. 2 (Apr-Jun.,1986), p. 249-74.

GOSSMAN, Lionel. Per me si va nella cittá dolente: Burckhardt and the Polis. In: Bulletin of the Institute of Classical Studies. Supplement, n. 79, Out of Arcadia: Classics and politics in Germany in the age of Burckhardt, Nietzsche and Wilamowitz, 2003, p. 47-59.

GUARINELLO, Norberto Luiz. Modelos Teóricos sobre a Cidade do Mediterrâneo Antigo. In: FLORENZANO, Maria Beatriz; HIRATA, Elaine Farias Veloso (Org.). Estudos sobre a cidade antiga. São Paulo: Edusp, 2009. p. 109-19.

HINDE, John, R. Jacob Burckhardt and the crisis of modernity. Montreal: McGill-Queen's University Press, 2000.

IGGERS, George G. The German conception of History: The national tradition of historical thought from Herder to the present. Middletown: Wesleyan University Press, 1983 [1968].

LORAUX, Nicole. Elogio do Anacronismo. In: NOVAES, Adauto (Org.). Tempo e História. São Paulo: Cia. das Letras, 1992. p. 57-70.

MALATIAN, Teresa. Chateaubriand. In: MALERBA, Jurandir (Org.). Lições de História. Porto Alegre: FGV/PUCRS, 2010. p. 113-31. 
MALERBA, Jurandir. Thomas Carlyle. In: - (Org.). Lições de História. Porto Alegre: FGV; PUCRS, 2010. p. 191-209.

MARX, Christoph. Jacob Burckhardt in seiner zeit: das Bild der polis in seiner "Griechischen Kulturgeschichte”. Berlin: Grin, 1998.

MEIKISINS-WOOD, Ellen. Peasant-citizen and Slave: the foundations of Athenian democracy. New York: Verso, 1988. p. 22-8.

MOERBECK, Guilherme. Entre o ritual e a politica: Eurípides e a Guerra do Peloponeso. Curitiba: Editora Prismas, 2017.

MOERBECK, Guilherme. Guerra, politica e tragédia na Atenas Clássica. Jundiaí: Paco Editorial, 2014.

MOERBECK, Guilherme. Burckhardt among Basel, Berlin and Athens: the game of the Mirror. História Revista, Goiânia, 2018. [to be published].

MORLEY, Neville. Ancient history: key themes and approaches. New York: Routledge, 2000.

MOMIGLIANO, Arnaldo. Essays in ancient and modern historiography. Chicago: The University of Chicago Press, 2012.

MORALES, Fábio Augusto. A democracia ateniense pelo avesso. São Paulo: Edusp, 2014.

MURRAY, Oswyn. Introduction. In: BURCKHARDT, Jacob. The Greeks and Greek civilization. Translated by Sheila Stern. New York: St. Martin’s Griffin, 1999.

NIPPEL, Wilfried. Introductory remarks: Max Weber's “The City” revisited. In: MOLHO, Anthony; RAAFLAUB, Kurt; EMLEM, Julia (Org.). City States in Classical Antiquity and Medieval Italy. Michigan: The University of Michigan Press, 1991. p. 19-30.

OBER, Josiah. Political Dissent in democratic Athens: Intellectual critics of popular rule. New Jersey: Princeton University Press, 1998. p. 290-5.

RODRIGUES, Antonio Edmilson Martins. Jacob Burckhardt. In: PARADA, Mauricio. (Org.). Os historiadores clássicos da História. Petrópolis: Vozes, 2013. p. 95-112.

SAKELLARIOU, M. B. The polis-state definition and origins. Athens: Medethmata, 1989.

SHEAR, Julia. Polis and revolution: responding to Oligarchy in Classical Athens. Cambridge: Cambridge University Press, 2011.

SIEBER, Marc; MÜLLER, Susanne. Le opere di Jacob Burckhardt: La storia singolare della loro edizione. Studi Storici, Anno 38, n. 1. p. 91-105, Jan.-Mar. 1997.

SIGURDSON, Richard. Jacob Burckhardt social and political thought. Toronto: University of Toronto Press, 2004.

SIGURDSON, Richard. Jacob Burckhardt: The cultural historian as political thinker. The Review of Politics, v. 52, n. 3, p. 417-40, Summer 1990. 
STOPPINO, Mario. Totalitarismo. In: BOBBIO, Norberto; MATTEUCCI, Nicola; PASQUINO, Gianfranco (Org.). Dicionário de Política. 5. ed. Brasília: UnB, 2004.

VLASSOPOULOS, Kostas. Unthinking the Greek polis: Ancient Greek history beyond eurocentrism. Cambridge: Cambridge University Press, 2007.

WEBER, Max. Economy and Society: an outline of interpretive sociology. Trad. Guenther Roth and Claus Wittich. Berkeley: University of California Press, 1978.

WILSON, Peter. The Athenian Institution of khoregia: The chorus, the city and the stage. Cambridge: Cambridge University Press, 2000. 
